\title{
A Study of the Genetic Variability of West Indian Arrowroot (Maranta arundinacea L.) in Kerala State of India
}

\author{
P. V. Shintu, V. V. Radhakrishnan, K. V. Mohanan \\ Genetics and Plant Breeding Division, Department of Botany, University of Calicut, Kerala, India
}

Email address:

itsmeshintu@gmail.com (P. V. Shintu), rkvadakkan@gmail.com (V. V. Radhakrishnan), drkvmohanan@rediffmail.com (K. V. Mohanan)

\section{To cite this article:}

P. V. Shintu, V. V. Radhakrishnan, K. V. Mohanan. A Study of the Genetic Variability of West Indian Arrowroot (Maranta arundinacea L.) in Kerala State of India. Agriculture, Forestry and Fisheries. Vol. 5, No. 5, 2016, pp. 186-190. doi: 10.11648/j.aff.20160505.17

Received: August 10, 2016; Accepted: August 19, 2016; Published: September 10, 2016

\begin{abstract}
West Indian arrowroot (Maranta arundinacea L.) is a major component of family farming in Kerala state of India. The starch obtained from its rhizomes is used both for food and nutraceutical purposes. A study was carried out to assess the genetic variability of West Indian arrowroot in the region in relation to morphological growth and yield characters. Sixty accessions collected from farmer homesteads were grown in the experimental garden and assessed for variability in terms of phenotypic coefficient of variation (PCV), genotypic coefficient of variation (GCV), heritability $\left(\mathrm{H}^{2}\right)$ and genetic advance (GA). High estimates of PCV, GCV, heritability and genetic advance in the case of the characters studied indicated the presence of substantial variability in the genetic resources of this important crop in the study area and also the scope for selection for crop improvement and release of promising varieties. Yield per plant showed the highest range of performance followed by starch content and leaf area. The minimum range of performance was observed for diameter of primary fingers. Wide range of characters indicates the involvement of higher number of contributing alleles and higher involvement of environmental factors in the expression of the character whereas narrow range indicates the involvement of lower number of contributing alleles and lesser involvement of environment. Heritability of characters varied from $16.69 \%$ to $99.22 \%$ and the highest heritability was shown by starch content, which was followed by plant height $(79.08 \%)$ and yield per plant (72.13\%). Genetic advance was found to be the maximum for starch content followed by number of primary fingers and number of tillers. The results indicate the occurrence of broad genetic base in the case of the Indian arrowroot populations studied and also the feasibility of selection of superior genotypes in Maranta arundinacea based on the characters that show broad range of variation.
\end{abstract}

Keywords: Genetic Variability, Heritability, Genetic Advance, Maranta arundinacea, Indian Arrowroot

\section{Introduction}

Ex situ conservation of landraces and wild relatives provides vital insurance against excessive erosion of a crop's genetic base. For this reason, gene bank collections have been established for all major and most minor crops. These repositories typically contain hundreds or even thousands of accessions originating from several geographic regions and representing a range of genetic backgrounds. Their utility for breeding purposes rests largely on the accuracy of evaluation and passport data, and also on the genetic fidelity of the material held. In the course of time, there is considerable scope for the accumulation of documentation errors that lead to wasteful duplication of stocks and also for genetic erosion to occur within accessions. Such events can be extremely difficult to detect but dramatically reduce the practical value of collections. There is a need, therefore, for a simple system to test the genetic identity and diversity of individuals within accessions and also to compare all accessions held within a collection [1].

Genetic variability assessment is the fundamental step towards the understanding of the genetic diversity of the populations of a species at a particular geographical area and it provides the raw material for the genetic improvement of the species [2]. Evaluation and characterization of the germplasm is necessary to identify qualitative and quantitative characters useful for breeding programmes. This study will accumulate genetic variability of the germplasm and affirm the presence of any genetic variability attributable 
to yield, an essential character in a breeding programme [3, 4]. Genetic variability, heritability along with genetic advance of traits, their association and direct and indirect effects on yield are essential for crop improvement in order to estimate the heritable and non-heritable variance which will give clues on possible improvement for the characters under study $[5,6]$. A comparison of plant morphology is the simplest approach for the detection of mislabeled accessions and the assessment of genetic diversity. This type of genetic diversity assessment does not require exorbitant technologies; rather require large area of land to conduct the field experiments. These means of morphological assessments are still having superiority and they are mandatory for identifying adult plants from genetic contamination in the field [1].

Improvement in any crop depends on the magnitude of genetic variability and the extent of transmission of characters from one generation to the next. Tuber crops occupy a remarkable position in the food security of the developing world due to their high calorific value and carbohydrate content. Some of them are already cultivated, but others are grown as a neglected group of economic plants [7]. Studies on their genetic diversity and the stability of their genetic base are very scarce. Maranta arundinacea L. (Indian arrowroot plant) is an important starch yielding tuber crop plant which finds uses in traditional food and medicine from the early days of human civilization. It belongs to the family Marantaceae [8]. This plant requires special attention being a good source of starch as well as a medicinal plant and hence the present study has been designed to assess the genetic variability, heritability and genetic advance of the morphological characters of the species using accessions collected from different parts of Kerala state, India.

\section{Materials and Methods}

Maranta arundinacea $\mathrm{L}$ is a perennial herb widely cultivated for its starchy rhizomes throughout the tropical countries of the world. The plant is erect, perennial and shallow rooted with rhizomes penetrating in to the soil. The plant thrives best in well drained loamy or sandy soil under partial shade [9].

Sixty accessions of Maranta arundinacea collected from different locations in the northern districts of Kerala state of India were used for the study (Table 1). The experiments were carried out in the experimental garden of the Genetics and Plant Breeding Division of Department of Botany, University of Calicut, Kerala, India. The experimental plot is located at $75^{\circ} 46^{\prime} \mathrm{E}$ longitude and $11^{\circ} 15^{\prime} \mathrm{N}$ latitude at an elevation of $50 \mathrm{~m}$ from MSL. The experimental area has got a tropical monsoon climate with south-west monsoon rains from June to August, north-east monsoon rains in OctoberNovember and dry spell from December to May with summer showers in March, April and May. Average temperature varies from $21.9^{\circ}-32.2^{\circ} \mathrm{C}$ and annual rainfall is about $290 \mathrm{~cm}$ [10]. The experiments were laid out in randomized block design (RBD) with 3 replications.
Healthy rhizomes were collected from the northern districts of Kerala during March/April 2013 and planted in the experimental garden in the first week of May 2013. The rhizomes were separated and each rhizome was planted in $38 \mathrm{~cm} \times 35 \mathrm{~cm}$ poly bag filled with garden soil, sand and enriched compost in 3:1:1 ratio. $2 \mathrm{~g}$ of NPK (18:18:18) was added at monthly intervals starting from the $30^{\text {th }}$ day of planting. Weeding was carried out regularly and optimum soil moisture was maintained. Data on growth, yield and rhizome characters were recorded by destructive sampling at maturity. Analysis of variance was carried out in the case of fourteen agronomic characters to find out the significance of variability. Phenotypic and genotypic coefficients of variation in the case of the above characters were worked out as per Singh and Choudhary (1985) [11], broad sense heritability as per Chahal and Gosal (2002) [12] and genetic advance as per Singh and Choudhary (1985) [11].

Table 1. Details of Maranta arundinacea accessions studied.

\begin{tabular}{|c|c|c|}
\hline Accession No. & Source & District \\
\hline CUW 1 & Chavakkad & Thrissur \\
\hline CUW 2 & Panambra & Malappuram \\
\hline CUW 3 & Varadoor & Wayanad \\
\hline CUW 4 & Areekode & Malappuram \\
\hline CUW 5 & Pathappiriyam & Malappuram \\
\hline CUW 6 & Kalikavu & Malappuram \\
\hline CUW 7 & Kuniyil & Malappuram \\
\hline CUW 8 & PuthurVayal & Wayanad \\
\hline CUW 9 & Villunnial & Malappuram \\
\hline CUW 10 & Mundakkulam & Malappuram \\
\hline CUW 11 & Alinchuvad & Malappuram \\
\hline CUW 12 & Vadakkummuri & Malappuram \\
\hline CUW 13 & Athinjal & Kasaragod \\
\hline CUW 14 & Kanjangad & Kasaragod \\
\hline CUW 15 & Trikkarippur & Kasaragod \\
\hline CUW 16 & Puthiyiruthi & Thrissur \\
\hline CUW 17 & Eramangalam & Malappuram \\
\hline CUW 18 & Punnayurkulam & Thrissur \\
\hline CUW 19 & Kanjiramukku & Malappuram \\
\hline CUW 20 & Pananthara & Thrissur \\
\hline CUW 21 & Nayarangadi & Thrissur \\
\hline CUW 22 & Kizhoor & Thrissur \\
\hline CUW 23 & Nakkola & Malappuram \\
\hline CUW 24 & Edakazhiyoor & Thrissur \\
\hline CUW 25 & Kanippayyur & Trissur \\
\hline CUW 26 & Anjoor & Thrissur \\
\hline CUW 27 & Mayanad & Calicut \\
\hline CUW 28 & Mangalassery & Malappuram \\
\hline CUW 29 & Parambilpeedika & Malappuram \\
\hline CUW 30 & Puthiyatheru & Kannur \\
\hline CUW 31 & Pavaratty & Thrissur \\
\hline CUW 32 & Monnamkallu & Thrissur \\
\hline CUW 33 & Edakkara & Thrissur \\
\hline CUW 34 & Kaplengad & Thrissur \\
\hline CUW 35 & Erinjoli & Kannur \\
\hline CUW 36 & Payyannur & Kannur \\
\hline CUW 37 & Ponnyam West & Kannur \\
\hline CUW 38 & Ponnyam East & Kannur \\
\hline CUW 39 & Kathiroor & Kannur \\
\hline CUW 40 & Kollanpadi & Malappuram \\
\hline CUW 41 & Kalpetta & Wayanad \\
\hline CUW 42 & Vazhavatta & Wayanad \\
\hline
\end{tabular}




\begin{tabular}{lll}
\hline Accession No. & Source & District \\
\hline CUW 43 & Munderi & Wayanad \\
CUW 44 & Karaparamba & Calicut \\
CUW 45 & Kannadikkal & Calicut \\
CUW 46 & Thamburanpadi & Thrissur \\
CUW 47 & Mangalam & Palakkad \\
CUW 48 & Iritty & Kannur \\
CUW 49 & Vavannoor & Palakkad \\
CUW 50 & Mulayankavu & Palakkad \\
CUW 51 & Kulukallur & Palakkad \\
CUW 52 & Nhangattiri & Palakkad \\
CUW 53 & Chalissery & Palakkad \\
CUW 54 & Kodakara & Thrissur \\
CUW 55 & Vetharkandam & Wayanad \\
CUW 56 & Athichal & Wayanad \\
CUW 57 & Kalluvayil & Wayanad \\
CUW 58 & Thamarassery & Calicut \\
CUW 59 & Cheruvathani & Thrissur \\
CUW 60 & Meenangadi & Wayanad \\
\hline
\end{tabular}

\section{Results and Discussion}

The mean, range, standard deviation and phenotypic and genotypic coefficients of variation with respect to characters of Maranta arundinacea studied are presented in Table 2. Variation in rhizome yield per plant is also presented in Fig. 1. Analysis of variance showed that the sixty accessions differed significantly for all the fourteen characters showing differences between them at genotypic level. Plant height varied from $70.02 \mathrm{~cm}$ to $144.97 \mathrm{~cm}$ with a mean of $121.5 \mathrm{~cm}$. Mean number of tillers per plant was 4.93 and it ranged from 1.22 to 9.89 . Number of leaves per tiller ranged from 6.92 to 24.74 and the mean value was 17.62. Leaf length varied from $24.84 \mathrm{~cm}$ to $33.9 \mathrm{~cm}$ and the mean value was $31.26 \mathrm{~cm}$. Leaf breadth showed a mean value of $10.8 \mathrm{~cm}$ and the range varied from $8.54 \mathrm{~cm}$ to $11.49 \mathrm{~cm}$. Leaf area ranged from $146.94 \mathrm{~cm}^{2}$ to $262.35 \mathrm{~cm}^{2}$ and the character showed a mean value of $233.97 \mathrm{~cm}^{2}$. Yield per plant ranged from $98.88 \mathrm{~g}$ to $521.94 \mathrm{~g}$ with a mean value of $324.81 \mathrm{~g}$. Number of rhizomes per plant ranged from 4.33 to 13.22 and the mean value was 8.56 . Rhizome length varied from $13.25 \mathrm{~cm}$ to $33.42 \mathrm{~cm}$ with a mean of $24.57 \mathrm{~cm}$. Diameter of rhizome varied from $1.66 \mathrm{~cm}$ to $3.12 \mathrm{~cm}$ with a mean value of $2.46 \mathrm{~cm}$. Number of primary fingers varied from 0.77 to 9.33 and the mean value was 2.71. Length of primary fingers varied from $2.64 \mathrm{~cm}$ to $14.34 \mathrm{~cm}$ with a mean value of $9.80 \mathrm{~cm}$. Diameter of primary fingers ranged from $0.73 \mathrm{~cm}$ to $4.27 \mathrm{~cm}$ and the mean value was $1.74 \mathrm{~cm}$. Starch content varied from $70.8 \mathrm{mg} \mathrm{g}^{-1}-$
$382.37 \mathrm{mg} \mathrm{g}^{-1}$ of fresh rhizome weight with a mean value of $180.79 \mathrm{mg} \mathrm{g}^{-1}$. Differential variability of quantitative characters in the case of cultivated plants and its application in crop improvement has been discussed by different workers in crops like coffee [13, 14], medicinal plants [15], cardamom [16, 17], cassia [18] and vanilla [19].

Phenotypic coefficient of variation (PCV), genotypic coefficient of variation (GCV) and heritability (broad sense) of characters can provide an idea of the extent of environmental impact on them, providing an estimate of inheritance of characters that can be expected from parent to progeny which is very essential in identifying superior genotypes and plant types for agronomic purposes. In the present experiment PCV was higher than GCV in all the cases except in starch content in which PCV and GCV were found to be almost equal. It shows that starch content has got the minimum influence of the environment in its expression.

Broad sense heritability of the characters ranged from $16.69 \%$ to $99.22 \%$. The highest heritability value of $99.22 \%$ was observed for starch content followed by plant height (79.08\%) and yield per plant $(72.13 \%)$ showing that these characters are influenced by environment to a very low extent. The minimum estimate of heritability was observed for length of primary fingers $(16.69 \%)$ indicating the highest influence of environmental factors on this character. Similar studies have been undertaken in different crops like coriander [20] and coffee [21].

Genetic advance was found to be the maximum for starch content $(70.75 \%)$ followed by number of primary fingers $(50.00 \%)$ and number of tillers $(49.65 \%)$. Genetic advance was low in the case of leaf length $(6.56 \%)$, leaf breadth (7.34\%) and length of rhizome $(7.43 \%)$. This shows that selection of superior genotypes in Maranta arundinacea can be based on characters like starch content, number of primary fingers, number of tillers and yield per plant in that order.

The fact that all the agronomic characters of Maranta arundinacea studied presently show significant variation between the accessions indicate the presence of a strong and diverse genetic base for the crop in the study area. However, utilization of this variability both for conservation and improvement of the species is essential since the crop is being marginalized due to changes in cropping patterns, utilization of agricultural land for other purposes and moreover, shifts in food habits of the local people from locally available crop diversity to commercial carbohydrate sources.

Table 2. Estimates of the genetic parameters of agronomic characters in Maranta arundinacea $L$.

\begin{tabular}{llllllll}
\hline Character & Range & Mean & $\begin{array}{l}\text { Standard } \\
\text { Deviation }\end{array}$ & $\begin{array}{l}\text { Genotypic } \\
\text { Coefficient of } \\
\text { Variation }\end{array}$ & $\begin{array}{l}\text { Phenotypic } \\
\text { Coefficient of } \\
\text { Variation }\end{array}$ & $\begin{array}{l}\text { Heritability } \\
\text { (Broad sense) (\%) }\end{array}$ & $\begin{array}{l}\text { Genetic } \\
\text { Advance (\%) }\end{array}$ \\
\hline Plant height $(\mathrm{cm}) * *$ & $70.02-144.97$ & 121.50 & 12.51 & 9.87 & 11.10 & 79.08 & 18.09 \\
Number of tillers ** & $1.22-9.89$ & 4.93 & 1.66 & 30.62 & 38.95 & 61.89 & 49.65 \\
Number of leaves per tiller ** & $6.92-24.74$ & 17.62 & 3.53 & 17.65 & 24.06 & 53.64 & 26.59 \\
Leaf length $(\mathrm{cm})^{* *}$ & $24.84-33.9$ & 31.26 & 1.37 & 4.00 & 5.05 & 63.05 & 6.56 \\
Leaf breadth $(\mathrm{cm}) * *$ & $8.54-11.49$ & 10.80 & 0.49 & 4.26 & 5.09 & 70.00 & 7.34 \\
Leaf area $\left(\mathrm{cm}^{2}\right)^{* *}$ & $146.94-262.35$ & 233.97 & 17.30 & 6.88 & 8.32 & 68.41 & 11.73 \\
Yield per plant $(\mathrm{g}) * *$ & $98.88-521.94$ & 324.81 & 84.27 & 24.42 & 28.75 & 72.13 & 42.72 \\
\hline
\end{tabular}




\begin{tabular}{llllllll}
\hline Character & Range & Mean & $\begin{array}{l}\text { Standard } \\
\text { Deviation }\end{array}$ & $\begin{array}{l}\text { Genotypic } \\
\text { Coefficient of } \\
\text { Variation }\end{array}$ & $\begin{array}{l}\text { Phenotypic } \\
\text { Coefficient of } \\
\text { Variation }\end{array}$ & $\begin{array}{l}\text { Heritability } \\
\text { (Broad sense) (\%) }\end{array}$ & $\begin{array}{l}\text { Genetic } \\
\text { Advance (\%) }\end{array}$ \\
\hline $\begin{array}{l}\text { Number of rhizomes per plant } \\
\text { ** }\end{array}$ & $4.33-13.22$ & 8.56 & 2.02 & 20.68 & 28.86 & 51.15 & 30.40 \\
Length of rhizome (cm)** & $13.25-33.42$ & 24.57 & 3.24 & 8.38 & 19.50 & 18.50 & 7.43 \\
Diameter of rhizome (cm)** & $1.66-3.12$ & 2.46 & 0.29 & 9.76 & 14.63 & 46.15 & 13.19 \\
Number of primary fingers** & $0.77-9.33$ & 2.71 & 1.34 & 39.48 & 64.58 & 37.58 & 50.00 \\
Length of primary fingers (cm)** & $2.64-14.34$ & 9.80 & 2.50 & 15.61 & 38.16 & 16.69 & 13.12 \\
$\begin{array}{l}\text { Diameter of primary fingers } \\
\text { (cm)** }\end{array}$ & $0.73-4.27$ & 1.74 & 0.49 & 18.39 & 41.96 & 18.52 & 16.01 \\
Starch content (mg g-1)** & $70.8-382.37$ & 180.79 & 62.42 & 34.48 & 34.61 & 99.22 & 70.75 \\
\hline
\end{tabular}

*: significant at $5 \%$ level; **: significant at $1 \%$ level.
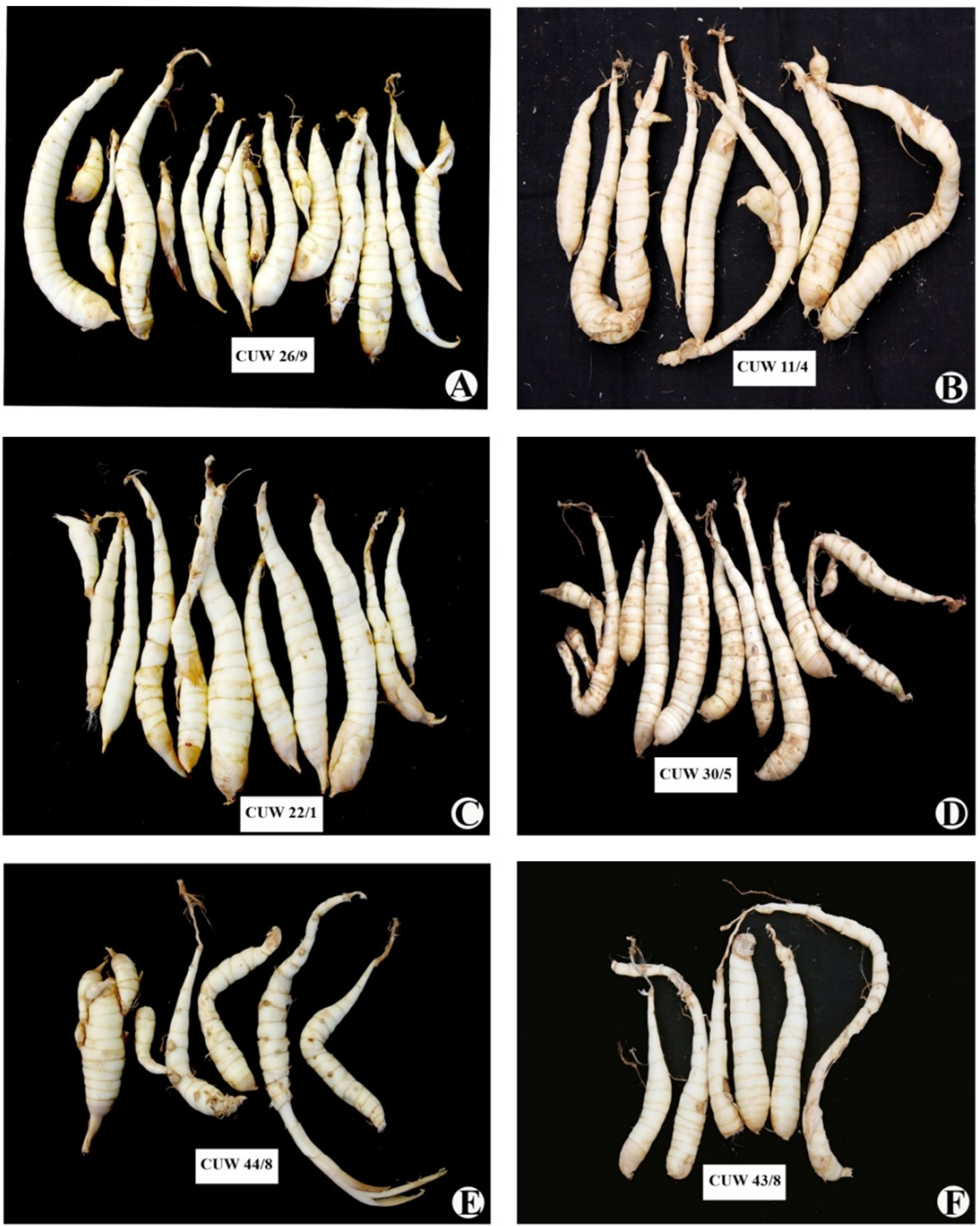

Fig. 1. Variation in rhizome yield in different accessions of Maranta arundinacea 


\section{References}

[1] Gilbert J. E., Lewis R. V., Wilkinson M. J. and Caligari P. D. S., 1999. Developing an appropriate strategy to assess genetic variability in plant germplasm collections. TAG Theoretical and Applied Genetics 98 (6): 1125-1131.

[2] Hughes A. R., Inouye B. D., Johnson M. T., Underwood N. and Vellend M., 2008. Ecological consequences of genetic diversity. Ecology Letters 11 (6): 609-623.

[3] Virmany S. S., Singh K. B. and Malhotra R. S., 1983. Evaluation of mung bean germplasm. Indian Journal of Genetics and Plant Breeding 43 (1): 54-58.

[4] Hakim L., 2013. Variability and correlation of agronomic characters of mung bean germplasm and their utilization for variety improvement program. Indonesian Journal of Agricultural Science 9 (1): 24-28.

[5] Rohman M. M., Hussain A. S. M. I., Arifin M. S., Akhter Z. and Hasanuzzaman M., 2003. Genetic variability, correlation and path analysis in mungbean. Asian Journal of Plant Sciences 2 (17-24): 1209-1211.

[6] Tabasum A., Saleem M. and Aziz I., 2010. Genetic variability, trait association and path analysis of yield and yield components in mungbean (Vigna radiata (L.) Wilczek). Pakistan Journal of Botany 42 (6): 3915-3924.

[7] Sujatha S. and Renuga F. B., 2013. Medicinal and edible tubers from forty two settlements of tribals from Pechiparai social forest in Kanyakumari District, India. Scholars' Academic journal of Bioscience 1 (5): 213-216.

[8] Andersson L., 1998. Marantaceae. In: Flowering PlantsMonocotyledons (Ed.: Kubitzki K.), Springer Verlag, Berlin Heidelberg, pp. 278-293.

[9] Anonymous, 1962. The Wealth of India: A Dictionary of Indian Raw Materials and Industrial Products- Vol. VI, Council of Scientific and Industrial Research, New Delhi, India. p. 483.

[10] Anonymous, 2011. Calicut Statistics and Info. www.Skyscrapercity.com

[11] Singh R. K. and Choudhary B. D., 1985. Biometrical Methods in Quantitative Genetic Analysis. Kalyani Publishers, New Delhi, India. p. 318.
[12] Chahal G. S. and Gosal S. S., 2002. Principles and Procedures of Plant Breeding- Biotechnological and Conventional Approaches. Narosa Publishing House, New Delhi, India. p. 604.

[13] Nikhila K. R., Reddy A. G. S., Sureshkumar, V. B. and Mohanan K. V., 2002. Consequences of sibmating in $\mathrm{C} \times \mathrm{R}$ (Coffea cognesis $\times$ Coffea canephora) coffee. In: Proceedings of PLACROSYM- XV, Central Coffee Research Institute, Balehonnur, Karnataka, India. pp. 83-87.

[14] Raghu A. V., Mohanan K. V., Reddy A. G. S. and Sureshkumar V. B., 2003. Variability in sibmating in $\mathrm{C} \times \mathrm{R}$ (Coffea cognesis $\times$ Coffea canephora) coffee. Indian Journal of Agricultural Research 37 (2): 110-114.

[15] Misra H. D., Sharma J. R., Lal R. K. and Sharma S., 1998. Genetic variability and path coefficient analysis in ashwagandha (Withania somnifera). Journal of Medicinal and Aromatic Plant Sciences 20: 753-756.

[16] Radhakrishnan V. V., Mohanan K. V. and Priya P. M., 2006a. Genetic variability in cardamom (Elettaria cardamomum Maton). Journal of Plantation Crops 34 (2): 87-89.

[17] Radhakrishnan V. V., Mohanan K. V. and Priya P. M., 2006b. Genetic divergence in cardamom (Elettaria cardamomum Maton). Journal of Plantation Crops 34 (3): 149-151.

[18] Chandramohanan K. T. and Mohanan K. V., 2005. Genetic control and phenotypic variability of morphometric characters in Cassia tora L. Agricultural Science Digest 25 (4): 275-277.

[19] Umamaheswari R. and Mohanan K. V., 2004. A study of field level variability of Vanilla planifolia in Kerala. Journal of Plantation Crops 32 (Suppl.): 98-99.

[20] Tripathi S. M., Kamaluddin, Srivastava S. B. L. and Srivastava J. P., 2000. Variability, heritability and correlation studies in coriander (Coriandrum sativum L.). In: Spices and Aromatic Plants- Challenges and Opportunities in the New Century (Eds: Ramana K. V., Eapen S. J., Nirmal Babu K., Krishnamurthy K. S. and Kumar A.), Indian Society for Spices, Calicut, India. pp. 30-34.

[21] Nikhila K. R., Sureshkumar V. B., Mohanan K. V. and Santharam A., 2008. Association of agronomic characters in robusta coffee (Coffea canephora Pierre ex Proehner). International Journal of Plant Breeding and Genetics 2 (1): 4750. 